\title{
Service-Learning Cross-Cultural Collaboration: Sustainable Actions in an Elementary School, Bagaces, Costa Rica
}

\author{
Katharine Leigh, $\mathrm{PhD}$ \\ Professor, Department of Design and Merchandising \\ Colorado State University \\ Fort Collins, Colorado 80523 \\ katharine.leigh@colostate.edu \\ Caroline M. Clevenger, $\mathrm{PhD}$ \\ Assistant Professor, Department of Construction Management \\ Colorado State University \\ Fort Collins, Colorado 80523 \\ caroline.clevenger@colostate.edu
}

\begin{abstract}
This paper examines the impact of the experience and learning outcomes from a problem-based, service-learning opportunity carried out within the context of a travel course focused on sustainable design and construction. Through a partnership between professional programs from two institutions of higher education, students from Colorado State University traveled to Costa Rica to meet their learning partners from the University of Costa Rica. During the travel course students participated in a one day service-learning project. The experience successfully emphasized the power of service-learning to impact student values, thinking and international understanding, reinforcing civic responsibility and social connectivity. As a mechanism to achieve cross-cultural understanding, this service-learning opportunity successfully invited exchange and appreciation of similarities, as well as differences, through collaborative problem solving, deepening student motivation both to learn and to engage. The study documented a unique and successful structure of international educational partnership(s) that supports international service-learning activities.
\end{abstract}

Index Terms - Construction, Design, Service-learning, Travel-course, Education

\section{UNIVERSITY PARTNERSHIP}

In 2009, Colorado State University (CSU) and the University of Costa Rica's (UCR) Architecture Department formed a partnership to create a 10-day travel study course focused on Sustainable Design and Construction. Taught on location at multiple sites within Costa Rica, the 3-credit course provided an opportunity to experience a rich, integrated service-learning experience for undergraduate and graduate students from multiple disciplines and native languages. The students worked toward the development of personal definitions and agendas encompassing sustainable practices, culminating in a team project incorporating sustainable design and development solutions. The students engaged in group problem-solving framed in Integrated Project Delivery to identify solutions and appropriate technologies. The American Institute of Architects (AIA) outlines Integrated Project Delivery to be an approach that a 
collaborative alliance of people, systems, business structures and practices is organized into a process to optimize project results. ${ }^{1}$

Participants from the U. S. and abroad (to date, China and Mexico) have included students enrolled in business, construction management, interior design, landscape architecture and practicing building professionals. Costa Rican (Ticos) participants have been students enrolled in architecture and business, as well as civil and industrial engineering practitioners.

Costa Rica, world renowned for its extreme range of bio-diversity, provides a dramatic and effective experiential backdrop to learn about climate-adaptive building practices. With a variety of outdoor and indoor classroom settings - under trees, on beaches, in computer labs, in meeting spaces and restaurants, the course incorporates lectures, multi-media and students presentations, discussions, and individual and group activities. Students primarily experience three distinct locations and climates across the Costa Rican landscape: Palo Verde (dry forest), Guanacaste (Pacific coastline), and Monte Verde (cloud forest). In such diverse settings students directly experience the interface of natural and constructed landscapes, with monkeys visiting classes, scorpions appearing in bathrooms, and fresh exotic juices served at every meal. This juxtaposition of nature and the built environment highlights potential synergies as well as conflicts. Furthermore, the sparse travel experience encourages personal resourcefulness as well as patience and understanding. Within this unique context such travel provides an exceptional backdrop for personal growth and learning about sustainability.

The course is distinct in providing such a learning environment; many U.S.-originated travel courses offered by a number of universities and in numerous disciplines make Costa Rica their destination. Few, however, are co-taught or co-attended by United States and Costa Rican professors and students. The unique collaboration provides an unparalleled, wholly integrated, cross-cultural, student-travel experience. Student feedback consistently identifies international student interaction as the biggest benefit, with cross-cultural discussions of sustainability as the most valuable learning component. Such a bi-cultural approach affords the group local opportunities and support otherwise unachievable in more traditional tourist or student travel settings. Furthermore, such cross-culture collaboration effectively mitigates the challenges of implementing service-learning in remote locations, including: project identification, project funding, trip and project logistics, health and safety of participants and building local trust and rapport. $^{2,3}$

Currently, the course is offered at the beginning of the calendar year, prior to the start of spring semester for students in the United States, and during summer break for Costa Rican students. This timing provides students the opportunity to attend the ten day travel course, without a full semester or summer commitment. While Costa Rica is located in the Northern Hemisphere and technically shares North America's seasons, winter and summer and the academic calendar in Costa Rica are opposite from the United States to accommodate Costa Rica's dry (summer) and wet (winter) seasons.

Learning objectives for the course include:

- defining concepts of sustainability, sustainable design, development, and construction;

- building a cross-disciplinary, cross-cultural, learning environment through student diversity, teamwork, and interdisciplinary project work;

- delivering an Integrated Project Delivery/Design (IPD) team project incorporating key sustainable features appropriate to the Costa Rican environment;

- gaining skills to identify and present sustainable project case studies; and

- developing knowledge of sustainable practices in diverse climates. 


\section{SERVICE-LEARNING COMPONENT}

In planning the 2012 course content, faculty collaborated to add a sustainability-oriented, service-learning experience to the course objectives and activities. While within a ten day travel course, time and scheduling opportunities are limited. Research suggests that even small-scale, short term (8-10 hr) service-learning experiences can provide valuable and measurable impacts on students' social responsibility beliefs, perceptions of meaningfulness, and likelihood of choosing a service-related occupation. ${ }^{4}$ Faculty identified the opportunity as an exceptional fit within the course experience because cross-cultural partnership was already a central pillar of the course structure. Students involved in service-learning generally show increases in international understanding. ${ }^{5}$ Although factors such as hours of service, contact with beneficiaries, and ongoing reflection impact the overall effectiveness of service-learning ${ }^{6}$, any opportunity for students from different cultures and countries to work together in service can be significant. Journaling for reflection was also already a required component of the learning process. Reflection is an important component of service-learning, distinguishing student efforts from community service. Service-learning is deeply rooted in the action-reflection theories of Dewey and Kolb, emphasizing the importance of combining individual action and engagement with reflective thinking to develop greater understanding of the content being studied. ${ }^{7}$

To facilitate the act of service, student partnerships and teamwork are required, and partnerships with the local community are invited and promoted. Particularly poignant for this course is the diversity of relationships and partnerships embodied by participants: foreign student/professor to national student/professor, national and foreign student to local community stakeholder. Such a unique blend of relationships and engagement provide a powerful setting for problem-based service-learning.

The scholarship of engagement, fueled by service-learning, has become a major national movement impacting higher education curricula. ${ }^{8}$ Service-learning is a pedagogy promoting educational experiences in which students participate in organized service activities meeting identified community needs to gain further understanding of course content and a broader understanding of the overall discipline. ${ }^{9}$ The hands-on aspect of the service learning model can be an effective teaching tool in design education where project-based and collaborative team learning has proven valuable. ${ }^{10}$ Specifically, service-learning positively impacts educational outcomes (i.e., problem analysis, critical thinking, and cognitive development). ${ }^{11,12}$ Servicelearning is frequently a good fit for educational programs related to the design, building and construction industries due to the applied nature of these disciplines, many of which already require experiential education in the form of internship, practicums, or co-operative service to graduate. ${ }^{13}$ Students and faculty report service-learning improves students' ability to apply what they have learned in the "real-world". 12,14

Service-learning connects academic study to community, which contributes to student learning that is deeper, longer lasting, and transferable to new challenges. This idea is a particularly powerful force in professional design study programs because knowledge is applied to problem solving in actual settings, and, in addition, communities are the recipients of "free" student design services. ${ }^{15}$

Al-Khafaji and Morse (2006) propose service-learning as an effective strategy to address the pressing need in engineering to better incorporate sustainability into curricula. ${ }^{16}$ In particular, service-learning serves as a compelling model in teaching sustainability emphasizing the cultivation of a sense of civic responsibility, engagement, and commitment to community. 
Service activities provide powerful experiences promoting a greater sense of stewardship toward the global context of community, particularly when carried out in a cross-cultural and international setting. Research findings suggest that service-learning has a positive effect on student's sense of social responsibility and citizenship. ${ }^{17,18}$ Recent findings indicate students who participate in service-learning have more sophisticated metacognitive abilities, better strategic planning and task analysis skills, better ability to discriminate useful from insignificant information, and better understanding of client needs and constraints. ${ }^{19}$

\section{Participants}

Nineteen participants (including 2 practicing engineers) enrolled in the course and agreed to participate in the service-learning experience; in addition, three faculty members from architecture (UCR), construction management (CSU), and interior design (CSU) joined in the work. Table I illustrates the group diversity, comprised of Costa Rican (42\%), American (53\%), and Chinese (5\%) participants.

TABLE I

PARTICIPANT CHARACTERISTICS BY GENDER, DISCIPLINE, NATIONALITY, AND AGE

\begin{tabular}{|c|c|c|c|c|c|c|c|}
\hline & \multirow{2}{*}{\multicolumn{2}{|c|}{$\frac{\text { University of Costa Rica (UCR) }}{\text { Costa Rican }}$}} & \multicolumn{5}{|c|}{ XXX University (XXX) } \\
\hline & & & \multicolumn{2}{|c|}{ United States } & \multicolumn{2}{|c|}{ Chinese } & \multirow[b]{2}{*}{ Total } \\
\hline & Male & Female & Male & Female & Male & Female & \\
\hline Gender & 3 & 5 & 6 & 4 & 1 & - & $19 *$ \\
\hline \multicolumn{8}{|l|}{ Discipline } \\
\hline Arch & 1 & 5 & - & - & - & - & 6 \\
\hline Civil Eng & 1 & - & - & - & - & - & 1 \\
\hline Con Mgt & - & - & 6 & 1 & 1 & - & 8 \\
\hline Indust Eng & 1 & - & - & - & - & - & 1 \\
\hline Int Design & - & - & - & 3 & - & - & 3 \\
\hline \multicolumn{8}{|l|}{ Age } \\
\hline 19 and under & & 2 & & & & & 2 \\
\hline $20-29$ & 3 & 3 & 3 & 4 & 1 & - & 14 \\
\hline $30-39$ & - & - & - & - & - & - & - \\
\hline $40-49$ & - & - & 3 & - & - & - & 3 \\
\hline Faculty** & 1 & - & - & 2 & - & - & 3 \\
\hline
\end{tabular}

$*$ three participants were graduate students $* *$ excluded from characteristics

On the day prior to the planned work day, the faculty members from architecture and interior design, with a graduate student from construction management, met to develop the approach, sequence, materials required, and to discuss the team coordination and safety requirements required to meet the goal of producing the service-learning goal: to provide nine desks and ten chairs to an elementary school in Bagaces, Costa Rica (see Figure 1 for anticipated project work flow). 


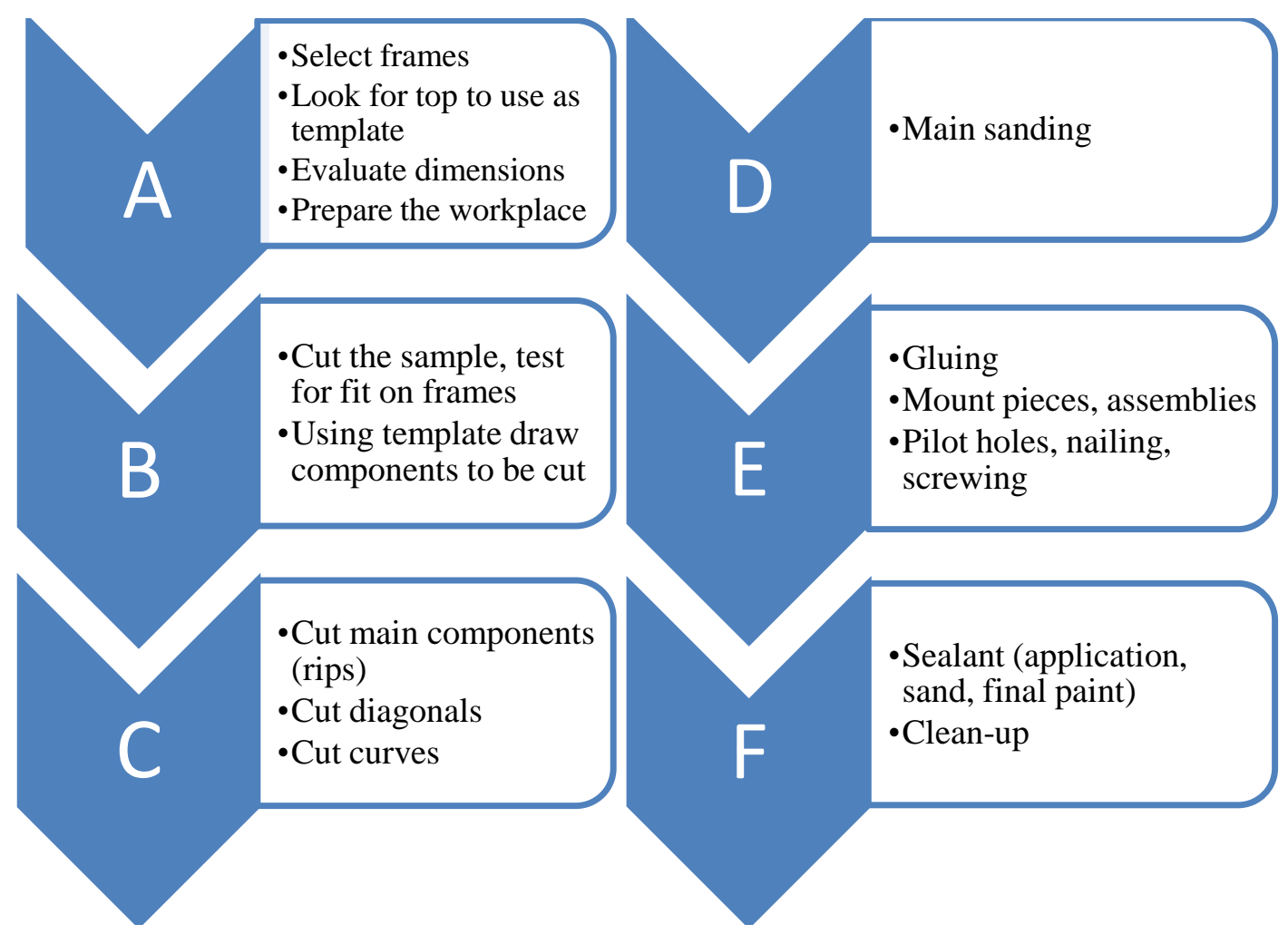

FIGURE 1

\section{ANTICIPATED WORKFLOW WITH INTERIM EVALUATION OF PROGRESS AND PROCESS}

The anticipated workflow was to create new chairs and desks by cutting and mounting new backs and seats to existing chair frames, and new desk tops and shelves to existing desk frames. Challenges anticipated included obtaining tools, conditions at the school site to support the work effort, and the energy and attitudes of the participants to engage in the project. Project goals included:

- Safety

- Learning

- Teamwork

- Giving back

- Having fun

These goals, along with the project plan, were reviewed with the participants in the evening before the work along with a discussion of how we would approach the start of the project. The conditions at the school were unknown; therefore, the approach initially included: assess the condition of the chairs and desks, develop a plan to use materials to the best advantage, as staging areas were created. The pre-planning meeting proved to be a powerful educational experience because it highlighted to all participants the strengths and frustrations of interdisciplinary collaboration. During the meeting the interior design and architecture students focused time and attention to the details of pre-planning. For example, using the work-flow diagram presented (Figure 1), they wanted to determine how many people would be needed for each task, and assign individuals to each group. The construction management students 
expressed skepticism that any of this pre-planning was valuable, especially when site conditions and availability of equipment and power supply were unknown. Loosely characterized, the designers championed a "detailed oriented, perfectionist" approach, while the construction management students championed a "let's wing it, problem-solve as we go, and get it done," approach. Many members of both groups expressed frustration at the end of this initial meeting, and many students questioned the value of the involvement of the other disciplines.

At the end of the meeting, faculty emphasized to all participants that it was critical for everyone to maintain a "what can I do and where can I help;" attitude; that if, the next day, anyone found him or herself standing around waiting to be told what to do, he or she was part of the problem. Finally, faculty encouraged everyone to remain flexible toward individual work preferences, skills, and experience.

\section{Project BaCkground}

Bagaces is a canton, or county, in Costa Rica's province of Guanacaste, spanning an area of more than 1,273 square kilometers (791+ miles). More than 18,000 people reside in the canton, roughly 190 kilometers from the capital city of San Jose, with a little under 10,000 people in the town of Bagaces proper, according to 2011 census figures recorded by the Nacional de Estadística y Censos. ${ }^{20}$ The country's seven provinces (provincias) are subdivided into 81 cantons or second level administrative divisions (counties), and further subdivided into districts (distritos). A unique feature of the cantons is that they are the only administrative division in Costa Rica possessing local government in the form of municipalities (municipalidad). Each municipality has its own mayor (alcalde) and several county representatives, all of them chosen via municipal elections (Concejo Municipal).

The project was initially identified by the Costa Rican faculty member. Initially, he contacted an international humanitarian agency to ask for suggestions. They pointed him to the Bagaces region. A second round of inquiries led to the school district in Bagaces, and the principal of the specific elementary school facility.

Schools in Costa Rica are funded for initial construction and furnishings by the government. Parents and grandparents typically organize to support the schools, carrying out fund-raising activities, and volunteering their time and assistance at each school. Several of the Costa Rican students noted that the farther removed from San Jose, the less attention and more forgotten these schools appear, in terms of upgrades to the physical environment. The Bagaces elementary school, the Escuela General Tomás Guardia Gutiérrez, was accessible via an unpaved road (28 $\mathrm{km}, 17$ miles), requiring a one hour bus ride by the students from the biological preserve where they were staying. When the group arrived, they found existing classrooms to be extremely worn (Figure 2). One U. S. students noted, "I couldn't help but think some of these desks and chairs would be considered at the end of their life cycle in the U. S. and they would have been replaced with new long ago". 


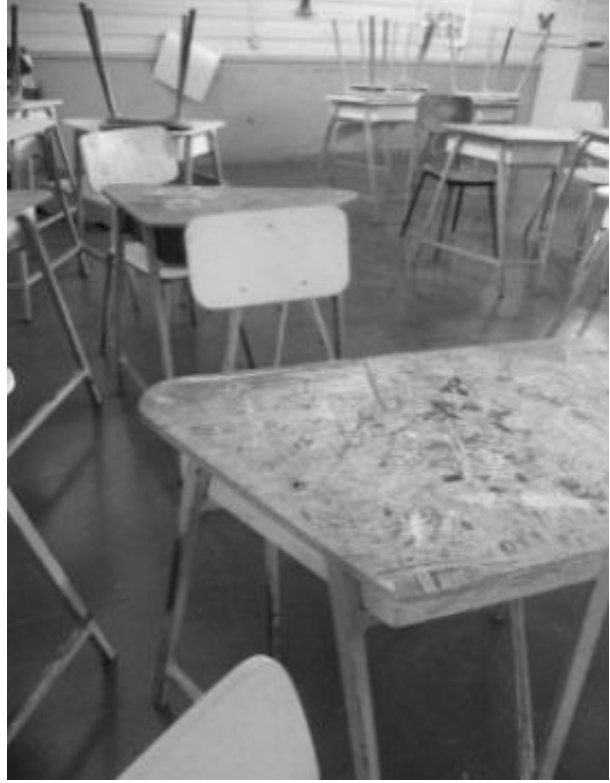

FIGURE 2

EXISTING CLASSROOM AT THE ESCUELA GENERAL TOMÁS GUARDIA GUTIÉRREZ

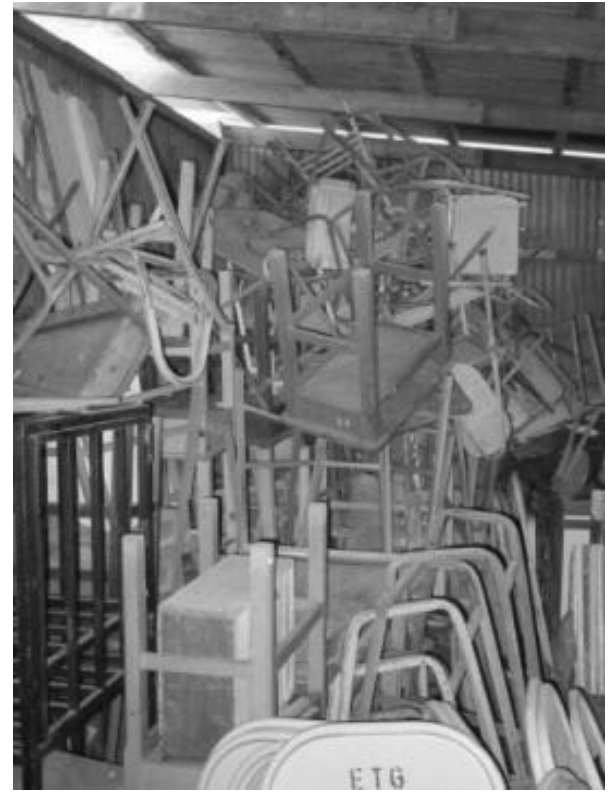

FIGURE 3

PILE OF DISCARDED, BROKEN CHAIRS AND DESKS IN A SHED. SCHOOLS IN COSTA RICA ARE UNABLE TO LEGALLY DISPOSE OF THEM

At the rear of the school adjacent to the sports courtyard, students discovered storage shed containing a large pile of discarded equipment and material from the school (Figure 3). Since government monies had secured the initial furniture and equipment, in Costa Rica it is against the law for the school to dispose of such equipment. As a result of this discovery, a new work plan was quickly devised where refurbished chairs and desks could be constructed out of salvaged pieces and parts from existing discarded equipment (Figure 4) and/or newly fabricated seats and desktops (Figure 5).

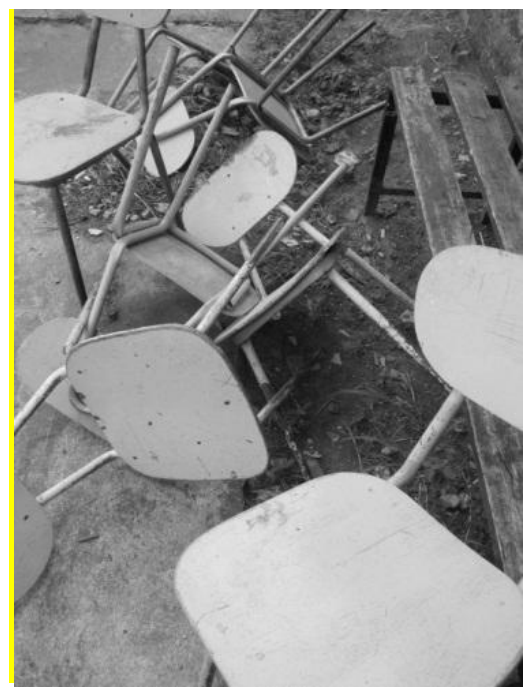

FIGURE 4

BROKEN AND DISCARDED CHAIRS WITH VARIOUS REUSABLE PARTS

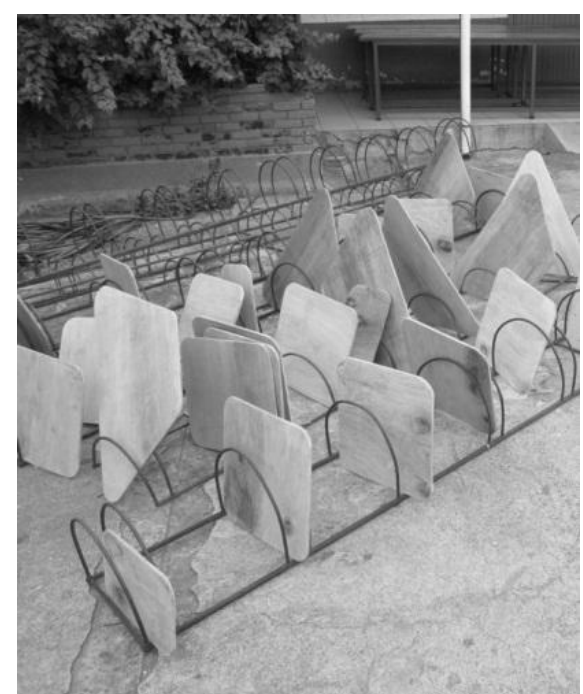

FIGURE 5

NEW SEATS AND DESK CONSTRUCTED BY STUDENTS OUT OF PLYWOOD 
With this new information, and after surveying the site, students quickly began their ad-hoc work-plan and set about the process of creating work areas to cut seat and back templates, and sort and assemble the useable components from the shed. All students took ownership of the new plan, which heightened motivation. The original goal of building nine or ten desks or chairs was quickly surpassed due to higher expectations. Work areas were set up to deconstruct chairs and desks and salvage components. Existing frames were evaluated for stability and strength, as well as sorting the frames that were available. Existing usable components were cleaned and sanded. At the same time new seats and tops were constructed from three $1.2 \mathrm{~m} \times 2.4 \mathrm{~m}$ (4ft $\times 8 \mathrm{ft}$ ) plywood sheets using a template cut by the students based on the salvaged components.

Collaborative teams began to self-form with individuals actively seeking a spot to help. Everyone, including the faculty, quickly became actively involved and worked tirelessly in the hot Costa Rican sun. A project manager (an experienced construction management student), selected unanimously by all, moved from group to group, helping to assess tasks, sequences, and production, and also monitoring opportunities for refurbishment. By midday when it was clear that initial goals would be exceeded, the entire group was excited about "giving more," and returned to work quickly. The school had initially supplied two cans of white paint. However, the interior design students exchanged the paint for a bright turquoise color. In the end, in less than six hours and using only very modest supplies costing a total of $\sim 209$ (2012) US dollars (104.500 CR colones) (Table II), 19 students with three faculty were able to construct 24 desks and 23 chairs painted and ready for use (Figure 6), with additional replacement surfaces for 14 more desk surfaces and chair components (seats and backs) sanded and sealed (refer to Figure 5). In the end, productivity exceeded expectations by $150 \%$. Several United States students commented that even greater progress could have been achieved with more and better tools. They suggested that the following year, the group should bring power tools to better equip the team.

TABLE II

PROJECT MATERIAL AND EQUIPMENT LISTS AND COSTS

\begin{tabular}{llll}
\hline Material & Quantity & \multicolumn{2}{c}{ Cost } \\
\hline $\begin{array}{l}\text { Plywood sheets } \\
1.2 \mathrm{~m} \text { x 2.4m (4ft x 8ft) }\end{array}$ & 3 & 60.000 & $\begin{array}{c}\text { United States } \\
\text { Dollars }\end{array}$ \\
\hline Paint (Gallon) (Turquois) & 2 & 15.000 & 120 \\
\hline Sealant (Gallon) & 1 & 13.000 & 30 \\
\hline Screws & $1 \mathrm{~kg}$ & 500 & 26 \\
\hline \hline Equipment & & & \\
\hline \hline Sandpaper & 10 & 2.000 & 4 \\
\hline Paint Brushes & 2 & 4.000 & 8 \\
\hline Misc Painting Supplies & & 10.000 & 20 \\
\hline Radial Power Saw & 1 & Borrowed & -- \\
\hline Electric Drill & 1 & Borrowed & -- \\
\hline Extension Cords & 2 & Borrowed & -- \\
\hline Screw Drivers & 3 & Borrowed & -- \\
\hline Hand Coping Saws & 2 & Borrowed & -- \\
\hline Music Supply & 1 & Borrowed & -- \\
\hline \multicolumn{1}{c}{ Total Cost: } & & 104.500 & $\$ 209$ \\
\hline \hline
\end{tabular}




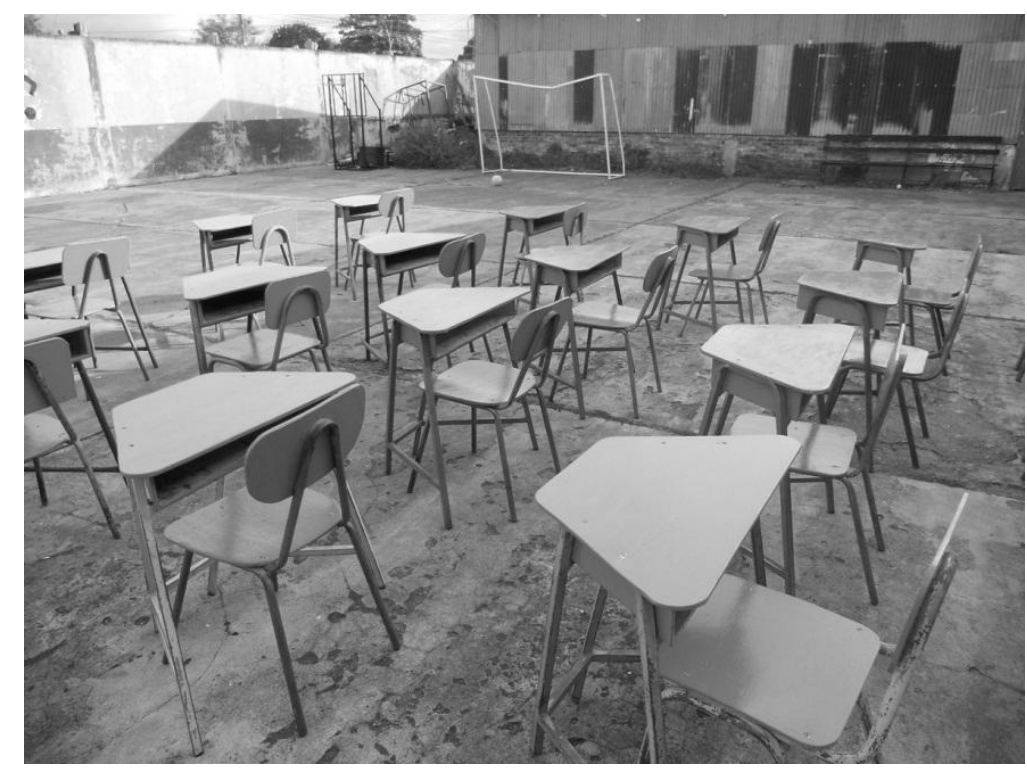

FIGURE 6

NEWLY CONSTRUCTED, ASSEMBLED, AND REFURBISHED CHAIRS AND DESKS

\section{Cross-CULTURAL INTERACTIONS}

Although students brought their own lunches, at lunch time three local women who later identified themselves as parents and grandparents of children attending the school, surprised the group with sandwiches and drinks. In the afternoon, they also offered coffee and empanadas (pies). One of the women shared that this was the first time they had received volunteer assistance of any kind. One Tico student later shared, "This experience gives us, Ticos, [an opportunity] to be closer to the schools and real world of...education [in Costa Rica]." A construction management student offered, "Although it proved effective as a team building experience..., the greatest benefit to me was the cultural and social exposure."

Research findings are multi-faceted and, at times, conflicted about the nature of, and powerrelationships inherent to international service learning. Cultural and ethical responsibilities surrounding development work are complex, and emphasis should be placed on community partnerships versus community hosts. ${ }^{21}$ Such research poses three guiding questions that organizers should ask when undertaking international service-learning projects:

“(1) How can we undertake appropriate interventions in other(s') communities that balance the enhancement of student learning with sustainable improvements and meaningful social change? (2) How can we create cross-cultural experiences that empower all participants while neither reinforcing nor exacerbating the social distance among them?

(3) How can we engage in responsible critique, yet not become paralyzed or cynical, so that we can continue to act and teach in a world that is characterized by so much self-interest, increasing disparity, and injustice?" 21

While the organizing faculty members did not directly address these specific questions during preparation, their assumptions and observations were that the multi-cultural make-up of the class 
served to significantly reduce the context of foreign development work and, instead, promoted meaningful and authentic community partnership.

\section{REFLECTIONS}

The next day, students were asked to reflect on the experience. Reflection is a key supporting element of any service-learning activity. Although, the service project was short in duration (one day), the unique nature of cross-cultural collaboration provided an opportunity for increased international understanding for all participants, including local citizens. In an effort to process and record such learning, students were verbally asked three questions:

- What did you learn?

- How did you feel about what you learned?

- What would you change?

Responses $(\mathrm{N}=19)$ were axial coded with six major themes surfacing from the narratives:

a) expectations

b) satisfaction

c) team work/team building

d) learning

e) added value/social responsibility

f) improvements

Sixty coded statements were initially generated from all responses. Over $31 \%$ focused on learning or a related aspect; roughly $6 \%$ could be attributed to team work, adding value/social responsibility and improvements.

\section{Expectations:}

Expectations were exceeded with students commenting about how well the work went with only very basic and scarce tools and materials - the tasks were certainly labor intensive. Students cited nervousness about how well they would work together, with excitement about working alongside each other; and good feelings were expressed about "being able to integrate everyone into the phases instead of how we planned it, separating the designers from the construction management participants." "That's how it is in construction; people can work in not so excellent conditions [and still have excellent results]. It's the way it should always be in a project, you give $100 \%$, so that the results can be better...Also important was the whole cultural exchange experience in doing this type of team work with other people, planning the process, talking about it and seeing the results." Another student shared, "I got to talk to a little boy that goes to the school - he was very happy when I told him what we were doing at the moment - then, you realize all the effort was worth it."

\section{Satisfaction:}

"We accomplished far more than I predicted and I believe that this occurred not because the job was less challenging than I thought it would be, but solely because I understood the abilities of our group...it was a great opportunity to open your eyes...and nice to help a school in need." The 
students, working side by side, created bonds that allowed cultural and disciplinary differences to blur into a camaraderie reinforced by the satisfaction of "doing a good job well - priceless." The experience and outcome created satisfaction on many levels. "We knew we were doing something good for the school but it was also frustrating because we could have done more." The general consensus was expressed in one student's entry, "[This] was the most rewarding day's work that I have participated in for many years; working with a group of inexperienced, young but eager students in a situation that was complicated and challenging; I was impressed over and over again with the seriousness and focus shown by both Costa Rican and U.S. students."

\section{Team work/Team building:}

The project created an understanding of team work that would have been hard to duplicate in other ways under the time constraints imposed on our productivity. "Everyone found his or her abilities [to]...produce...excellent work...It was important to work as a group, to know how to work with people from other careers and different ways of doing things. The...project helped [us] to [gain]... more knowledge about group work, to program to do the things in a better way and separate all the [individual] phases of the job to have good results as a team." In the end, "the entire group worked very efficiently given only one day to complete the project. It was extremely exhausting for everyone working ...[in the heat and humidity...but] as a group we can overcome design obstacles and learn how to create a successful sustainable design." Students saw the benefits of identifying a project manager, commenting "having a project manager really helped the flow of work to occur" with insights offered and oversight helping to envision the outcome during the process, allowing shifts in the work effort to be smoothly achieved. For some, worries of too many cooks in the kitchen were initially expressed. But in the end, "Everyone [had his or her] own job and completed the job on schedule. Beginning of the service was obviously a little messy because we [knew] so little about the amount of [work] needed to be done...it cost some time to figure out the target...but we controlled [the work]... well. Getting information - discussing - assigning job - work shifting [to improve productivity] - job completion - checking quality. The whole procedure was connected ...well."

\section{Learning:}

The pre-project planning helped to frame expectations before accessing the site conditions and provided a valuable learning experience regarding interdisciplinary work. "The planning we did was really good; it saved a lot of the limited time we had." The Americans commitment and way of getting things done is inspiring." Although the stated course objectives focused on sustainability, in their reflections, students embraced the more encompassing notion that "this class is also about giving to other[s] and giving to communities and getting out of your comfort zone." Another student stated, "To make a new chair back, seat and desk top and largely use the remaining parts from the waste materials was ...putting sustainable knowledge into practice. Even though the service was on the chairs and desks it enlightened me about recycling materials for construction [and] tells the truth that environment, economics, and people are closely related." Sweat equity contributed to the learning, "willing hands are just as valuable as tools or materials; when we faced challenges we used our many brains and hands to overcome it...the highlight of the trip so far." Awareness of environmental, cultural and economic differences also surfaced as one student commented, "I realized how lucky we all have been in the US to have the 
modern school facilities that we [take for granted]." The majority of students informally commented about the value of giving back, doing service and volunteering, forgetting how it made them feel and making a majority commit to doing more service-learning, finding the experience "incredibly inspiring."

\section{Added value/Social responsibility:}

This experience "allowed us to see through the eyes of children in other parts of the world and reflect on the ability that we all possess - to give back. Day to day life activities in the states prevents most from seeing the simple needs of others. The school [service-learning] experience tied well to the themes of sustainability and related construction practices...I really felt I was giving a valuable gift to the community." As previously mentioned, several Ticos noted the powerful impact of helping individuals in their own rural communities, and contributing to other's education in particular. Many students stated that such an experience motivated them to want to do more community service in the future.

The six emergent themes of the reflections and their coded content serve to validate and emphasize the five course learning objectives, as previously presented.

\section{IMPACT AND LESSONS LEARNED}

Research on creativity in work environments suggests intrinsic motivation is an essential component impacting creative outcomes. The on-site learning in this environment required students to take an active role in directing their learning. Motivations varied at the start of the course; with not all students engaged in classroom discussions. The service-learning day occurred on the $4^{\text {th }}$ day after formal and informal lectures and discussions had paved the way for thinking about re-use and repurposing of materials, personal eco-footprints, and foundational concepts in sustainable action.

Service-learning among the built environment disciplines promotes and invites intrinsic motivation, embracing real-world design thinking focused on sustainable principles. This thinking is reinforced by community partnership and engagement ingraining value to the experience. The interdisciplinary, multicultural backgrounds of the participants also reinforced differences in problem seeking and solving approaches inviting greater appreciation and understanding of cross-disciplinary perspectives and contributions.

Primary lessons learned included:

- Having many, small low-tech activities (disassembly, sanding, assembly, painting etc.) significantly aided work-flow and motivation. It resulted in nearly continuous, 100\% participation leading to greater productivity and team building.

- Holding the service-learning day early in the course had the significant added benefit of creating an effective and lasting ice-breaker between disciplines and cultures.

- Participating in one 6 hour service-learning project provided a powerful and illustrative cross-cultural and cross-disciplinary model unobtainable through lecture alone.

- Implementing service-learning in a cross-cultural, inter-disciplinary class structure mitigates many of the logistical and cultural challenges typical of many service-learning projects.

Students generated ideas for a follow-up project during the next course offering focusing on the sustainable features of the facility. Many of these ideas were based on direct observation of 
need at the school. For example, students noticed that severe damage had been done to the roof, and the surfaces of the covered walkways due to heavy rain and a lack of containment. Students also observed uneven walkways, crumbling planters built around columns with signage and other integrated elements. Students observed the impact of facility conditions on student circulation, safety and health. They identified the potential to improve existing conditions, address water resources and efficiency and growth of natural plantings in the outdoor courtyards as possible next service-learning projects to improve the quality of the learning environment for the students while effecting improved sustainability for the facility.

In future projects, faculty will seek greater opportunity to more deeply examine the complex social and cultural issues that may arise in the service relationships created between students and the community, particularly in international settings. Cross-cultural collaboration provides a rich and personal illustration of the complexity of power and equity issues facing the world. In the future, such service activities and reflection may be used to play a key role in raising international understanding for both students and citizens.

\section{ACKNOWLEDGMENT}

The authors would like to thank and acknowledge Alejandro Ugarte, Professor of Architecture at the University of Costa Rica. Mr. Ugarte was one of the original founders of the CSU-UCR course, currently in its sixth offering. His architectural expertise, sustainable knowledge, and cultural leadership have been invaluable both in the development of this paper and the overall success of the course.

\section{REFERENCES}

${ }^{1}$ American Institute of Architects (AIA) California Council (2007), Integrated Project Delivery - A Working Definition. Retrieved 08/26/12 from http://ipdca.net/images/Integrated\%20Project\%20Delivery\%20Definition.pdf

2 Simon, M., Bixler, G., Doudican, B., Dzwonczyk, R., Engineering Service-Learning - Importance of Appropriate Collaboration with International Partners International Journal for Service Learning in Engineering Vol. 7, no. 1 (2012), pp. 28-39.

3 Skokan, C. and Munoz, D. (2007). Humanitarian Engineering Program - Challenges in the Execution of Remote Projects. International Conference on Engineering Education (ICEE 2007), Coimbra, Portugal, Sept. 307. Paper 204. http://icee2007.dei.uc.pt/proceedings/papers/204.pdf

${ }^{4}$ Reed, V., Jernstedt, G.C., Hawley, J.K., Reber, E.S., DuBois, C.A., (2005) Effects of a small-scale, very short-term service-learning experience on college students, Journal of Adolescence Vol. 28, no. 3 (2005), pp. 359-368.

5 Myers-Lipton, S. Effect of Service-Learning on College Students' Attitudes toward International Understanding. Journal of College Student Development Vol. 37, no. 6 (1996): 659-68.

${ }^{6}$ Mabry, B.J., Pedagogical Variations in Service-Learning and Student Outcomes: How Time, Contact, and Reflection Matter. Michigan Journal of Community Service Learning Vol. 5 (1998), pp. 32-47.

${ }^{7}$ Crews, R., Benefits of service-learning. Communications for a Sustainable Future. (Boulder, CO: University of Colorado at Boulder, 1999).

${ }^{8}$ Boyer, E., The scholarship of engagement. Journal of Public Service and Outreach, Vol. 1, no. 1 (1997), 11-20.

${ }^{9}$ Hatcher, J. A., \& Bringle, R. G., Reflection: Bridging the gap between service and learning. College Teaching, Vol. 45, no. 4 (1997), 153-158.

${ }^{10}$ Dym, C., Agogino, A., Eris, O., Frey, D., \& Leifer, L., Engineering design thinking, teaching, and learning. Journal of Engineering Education, Vol. 94, no. 1 (2005), 103-20. 
11 Batchelder, T. H. \& Root, S., Effects of an undergraduate program to integrate academic learning and service: Cognitive, prosocial cognitive, and identity outcomes. Journal of Adolescence, Vol. 17, no. 4 (1994), 341-355.

12 Eyler, J., \& Giles, D., Where's the learning in service-learning? (San Francisco, CA: Jossey- Bass, 1999).

${ }^{13}$ McCrary, S. W., Peterson, D., Strong, S., Service learning in an introductory course in construction management. Journal of Industrial Technology, Vol. 23, no. 2 (2007), 1-12.

${ }^{14}$ Fenzel, L. M. \& Leary, T., Evaluating outcomes of service-learning courses at a parochial college. (Paper presented at the annual meeting of the American Educational Research Association, Chicago, IL., 1997).

${ }^{15}$ Zollinger, S. W., Guerin, D. A., Hadjiyanni, T., \& Martin, C. S., Deconstructing service-learning: A framework for interior design. Journal of Interior Design, Vol. 34, no. 3 (2009), 31-45.

${ }^{16}$ Al-Khafaji, K. \& Morse, M., Learning sustainable design through service, International Journal for Service Learning in Engineering, Vol. 1, no. 1 (2006), 1-10.

17 Astin A. W. \& Sax, L. J., How undergraduates are affected by service participation. Journal College Student Development, Vol. 39 (1998), 251-63.

18 Astin, A. W., Sax, L. J., \& Avalos, J., Long-term effects of volunteerism during the undergraduate years. The Review of Higher Education, Vol. 22 (1999), 187-202.

${ }^{19}$ Lemons, G., Carberry, A., Swan, C., Jarvin, L., Effects of Service-Based Learning on Meta-Cognitive Strategies. International Journal for Service Learning in Engineering, Vol. 6, no. 2 (2011), 1-18.

${ }^{20}$ National Institute of Statistics and Census of Costa Rica., Census figures for Bagaces, Costa Rica (2011). Retrieved (7/25/12) from http://www.inec.go.cr/Web/Home/pagPrincipal.aspx.

${ }^{21}$ Crabtree, R. D. Theoretical foundations for international service-learning. Michigan Journal of Community Service Learning Vol. 15, no. 1 (2008): 18-36. 